\title{
Announcing the winner of the John J. Sciarra IJGO Prize Paper Award for 2011
}

\begin{tabular}{|c|c|}
\hline \multicolumn{2}{|c|}{ International Journal of Gynecology and Obstetrics 115 (2011) 224-226 } \\
\hline \multicolumn{2}{|l|}{ CLINICAL ARTICLE } \\
\hline \multicolumn{2}{|c|}{$\begin{array}{l}\text { Effect of intravenous tranexamic acid administration on blood loss during and after } \\
\text { cesarean delivery }\end{array}$} \\
\hline \multicolumn{2}{|c|}{ Ali Movafegh ${ }^{a}$, Laleh Eslamian ${ }^{\text {b,* }}$, Azita Dorabadi ${ }^{c}$} \\
\hline \multicolumn{2}{|c|}{$\begin{array}{l}\text { a Anesthesia and Analgesia Department, Shariati Hospital, Tehran University of Medical Sciences, Tehran, Iran } \\
\text { b Perinatology Division, Obstetrics and Gynecology Department, Shariati Hospital, Tehran University of Medical Sciences, } \\
\text { Tehran, Iran } \\
{ }^{c} \text { Obstetrics and Gynecology Department, Shariati Hospital, Tehran University of Medical Sciences, Tehran, Iran }\end{array}$} \\
\hline A R T I C LE I N F O & A B S T R A C T \\
\hline $\begin{array}{l}\text { Article history: } \\
\text { Received } 24 \text { March } 2011 \\
\text { Received in revised form } \\
4 \text { July } 2011 \\
\text { Accepted } 2 \text { August } 2011 \\
\text { Keywods: } \\
\text { Blood loss } \\
\text { Cesarean delivery } \\
\text { Hemorrhage } \\
\text { Oxytocin } \\
\text { Tranexamic acid }\end{array}$ & $\begin{array}{l}\text { Objective: To assess the effect of intravenous tranexamic acid on blood loss dur- } \\
\text { ing and after cesarean delivery. Methods: One hundred pregnant women were } \\
\text { randomized to receive either } 10 \mathrm{mg} / \mathrm{kg} \text { of tranexamic acid or placebo intrave- } \\
\text { nously } 20 \text { minutes before incision in a double-blind controlled study. Postplacen- } \\
\text { tal delivery blood loss, postoperative hemorrhage } 2 \text { hours after surgery, and } \\
\text { oxytocin administration were recorded. Results: The patients' mean age, weight, } \\
\text { and duration of surgery were similar between the } 2 \text { groups. Mean blood loss was } \\
\text { significantly less in the tranexamic acid group compared with the control group } \\
\text { for both intraoperative bleeding ( } 262.5 \pm 39.6 \text { vs } 404.7 \pm 94.4 \mathrm{~mL} \text { ) and postoper- } \\
\text { ative bleeding ( } 67.1 \pm 6.5 \text { vs } 141.0 \pm 33.9 \mathrm{~mL} ; P<0.001) \text {, respectively. Oxytocin } \\
\text { administration was significantly less in the tranexamic acid group compared } \\
\text { with the control group ( } 39 \pm 5.8 \text { vs } 43 \pm 5.4 \text { units; } P=0.001 \text { ). Conclusion: Intra- } \\
\text { venous tranexamic acid decreased intra- and postoperative blood loss and oxyto- } \\
\text { cin administered in patients delivered by cesarean. } \\
\text { (c) } 2011 \text { Published by Elsevier Ireland Ltd. on behalf of International Federation of } \\
\text { Gynecology and Obstetrics. }\end{array}$ \\
\hline
\end{tabular}

The editors of the International Journal of Gynecology and Obstetrics (IJGO) are pleased to announce the winner of the prize award for the best clinical research paper from a low/middle-income country published in the IJGO during 2011. The winning paper is by A. Movafegh, L. Eslamian, and A. Dorabadi, from Shariati Hospital, Tehran University of Medical Sciences, Tehran, Iran. The paper is "Effect of intravenous tranexamic acid administration on blood loss during and after cesarean delivery" Int J Gynecol Obstet 2011; 115(3): 224-226. It was published in the December 2011 issue of the IJGO.

This award brings with it a stipend of $€ 1000$, a 1-year subscription to ScienceDirect, Elsevier's web database of journals, reference works, and book series (www.sciencedirect.com), and an award certificate for each of the authors.

All clinical research articles submitted to the IJGO from low/ middle-income countries that were published in 2011 were considered for this prize. The paper was chosen from over 100 qualifying articles. Selection was made by the editors and was endorsed by the editorial board of the IJGO.

Additional papers that are worthy of special recognition are awarded an honorable mention. While the honorable mention recognition does not include a financial award, each author receives a certificate of recognition and a letter of commendation from the editors of the IJGO.

The IJGO Prize Paper Award was established in 1998 for the purpose of encouraging investigators, especially young scientists, from low/middle-income countries to submit their best clinical research articles for publication in the Journal. The IJGO is the official publication of the International Federation of Gynecology and Obstetrics (FIGO), the primary international organization for the specialty of obstetrics and gynecology. FIGO is dedicated to enhancing the healthcare of women worldwide. 
The following 11 papers receive an honorable mention.

\section{Honorable mentions 2011}

\section{South Africa}

Hofmeyr GJ, Fawole B, Mugerwa K, Godi NP, Blignaut Q, Mangesi L, Singata M, Brady L, Blum J. Administration of $400 \mu \mathrm{g}$ of misoprostol to augment routine active management of the third stage of labor. Int J Gynecol Obstet 2011;112(2):98-102.

\section{Egypt}

Sayed GH, Zakherah MS, El-Nashar SA, Shaaban MM. A randomized clinical trial of a levonorgestrel-releasing intrauterine system and a low-dose combined oral contraceptive for fibroid-related menorrhagia. Int J Gynecol Obstet 2011;112(2):126-130.

\section{Nigeria}

Fawole AO, Sotiloye OS, Hunyinbo KI, Umezulike AC, Okunlola MA, Adekanle DA, Osamor J, Adeyanju O, Olowookere OO, Adekunle AO, Singata M, Mangesi L, Hofmeyr GJ. A double-blind, randomized, placebo-controlled trial of misoprostol and routine uterotonics for the prevention of postpartum hemorrhage. Int J Gynecol Obstet 2011;112(2):107-111.

\section{India}

Mittal S, Sehgal R, Aggarwal S, Aruna J, Bahadur A, Kumar G. Cervical priming with misoprostol before manual vacuum aspiration versus electric vacuum aspiration for first-trimester surgical abortion. Int J Gynecol Obstet 2011;112(1):34-39.

\section{Russia}

Pushkar DY, Godunov BN, Gvozdev M, Kasyan GR. Complications of mid-urethral slings for treatment of stress urinary incontinence. Int J Gynecol Obstet 2011;113(1):54-57.

\section{Pakistan}

Karim SA, Nusrat U, Aziz A. Vitamin D deficiency in pregnant women and their newborns as seen at a tertiary-care center in Karachi,
Pakistan. Int J Gynecol Obstet 2011;112(1):59-62.

\section{Kosovo}

Paçarada M, Zeqiri F, Kongjeli N, Kongjeli G, Obërtinca B. Misoprostolinduced abortions in Kosovo. Int J Gynecol Obstet 2011;112(2):116-118.

\section{Jamaica}

Christie LR, Harriott JA, Dacosta VE, Wynter SH, Everett DM, Foster RA. Intrauterine insemination in Jamaica as a low-cost subfertility treatment in a low-resource region . Int J Gynecol Obstet 2011;112(3):208-210.

\section{Ghana}

Issah K, Nang-Beifubah A, Opoku CF. Maternal and neonatal survival and mortality in the Upper West Region of Ghana. Int J Gynecol Obstet 2011;113(3):208-210.

\section{Kenya}

Weston K, Mutiso S, Mwangi JW, Qureshi Z, Beard J, Venkat P. Depression among women with obstetric fistula in Kenya. Int J Gynecol Obstet 2011;115(1):31-33.

\section{Uganda}

Atuhairwe S, Busingye RB, Sekikubo M, Nakimuli A, Mutyaba T. Urologic complications among women with advanced cervical cancer at a tertiary referral hospital in Uganda. Int J Gynecol Obstet 2011;115(3): 282-284.

Timothy R.B. Johnson M.D. Editor International Journal of Gynecology and Obstetrics, Bates Professor of the Diseases of Women and Children, Chairman of the Department of Obstetrics and Gynecology, University of Michigan, Ann Arbor, MI, USA E-mail address: trbj@med.umich.edu. 